\title{
Population dynamics and metabolism of Aequipecten opercularis (L.) from the western English Channel (Roscoff, France)
}

\author{
Olaf Heilmayer*, Thomas Brey, Daniela Storch, Andreas Mackensen, Wolf E. Arntz \\ Alfred Wegener Institute for Polar and Marine Research, P.O. Box 120161, 27515 Bremerhaven, Germany
}

Received 17 March 2003; accepted 18 July 2003

\begin{abstract}
Population dynamics of the queen scallop, Aequipecten opercularis, was investigated in the western English Channel off Roscoff. Annual formation of natural growth rings on the shell surface was validated by stable isotope $\left(\delta^{18} \mathrm{O}\right.$ and $\left.\delta^{13} \mathrm{C}\right)$ analysis. A von Bertalanffy growth function $\left(H_{t}=58.9 \mathrm{~mm} \bullet\left(1-\mathrm{e}^{-0.604 \bullet(t+0.235)}\right)\right)$ was fitted to size-at-age data of 249 individuals. Annual somatic and gonad production amounted to $19.74 \mathrm{~kJ} \mathrm{~m}^{-2}$ and $0.98 \mathrm{~kJ} \mathrm{~m}^{-2} \mathrm{y}^{-1}$, respectively. Total mortality rate $\mathrm{Z}$ was estimated to be $1.716 \mathrm{y}^{-1}$. Net growth efficiencies (ranging from $45 \%$ in 1 -y-old to $11 \%$ in 6 -y-old individuals) were in the same range as in other short-lived scallops. Individual growth, however, was distinctly slower in this population than in other A. opercularis populations from similar latitudes, most likely due to a more stressful environment.

(C) 2004 Elsevier B.V. All rights reserved.
\end{abstract}

Keywords: Bivalvia; Energy budget; Metabolism; Mortality; Pectinidae; Population dynamics

\section{Introduction}

The commercially exploited queen scallop Aequipecten opercularis (L.) occurs throughout a wide geographical range on the European continental shelf: from northern Norway to the Mediterranean and from the Adriatic to the west of Ireland (Broom, 1976; Brand, 1991; Waller, 1991). Recruitment success and spatial distribution appear to be highly variable in time, thus inducing major year-to-year changes in extent and position of scallop banks of exploitable

* Corresponding author. Tel.: +49-471-4831-1320; fax: +49471-4831-1149.

E-mail address: oheilmayer@awi-bremerhaven.de (O. Heilmayer). size and density, as reported from British waters (Broom, 1976; Brand, 1991) as well as from the eastern part of the English Channel and from northern Brittany (Grainger, 1992; Goulletquer and Heral, 1997). Due to the relatively short time $A$. opercularis can be kept fresh (Ansell et al., 1991), queen scallops support only a small local fishery and market in France, which is about $1 / 8$ of total French scallop landings (Grainger, 1992).

In contrast to the great scallop (Pecten maximus L.), interest in population dynamic parameters of $A$. opercularis has hitherto been limited. Paul (1980) investigated salinity and temperature tolerances, Vahl (1972) described the relationship between water transport and oxygen uptake, and McLusky (1973) determined the effect of temperature acclimation on filtration and oxygen consumption rates. 
Data on age and growth have been reviewed by Taylor and Venn (1978). Little is known, however, on population biology and production of the queen scallop populations in the western English Channel, besides the growth rates determined by Franklin et al. (1980).

A baseline study on the biology and population dynamics of $A$. opercularis in the western English Channel is presented. In this study growth, mortality, age-specific somatic and gonadal production as well as metabolic rates in individual scallops were calculated and compared with previous findings in the literature.

\section{Material and methods}

\subsection{Study site and general measurements}

Queen scallops (Aequipecten opercularis) were collected with a small dredge in the western English Channel next to Roscoff (Trezen Vraz, $48^{\circ} 59^{\prime} \mathrm{N}$, $4^{\circ} 53^{\prime} \mathrm{W}$ ) in 60 to $80 \mathrm{~m}$ water depth at three times (February, June and October) in 1999. Water temperature varied between $9.7^{\circ} \mathrm{C}$ in January/February and $16.4{ }^{\circ} \mathrm{C}$ in August (Fig. 1). The summer phytoplankton bloom consisted of two peaks, with a maximum of $1.53 \mu \mathrm{g}^{-1}$ in April, and a second one amounting to $1.56 \mu \mathrm{g}^{-1}$ by late August. Minimum chlorophyll

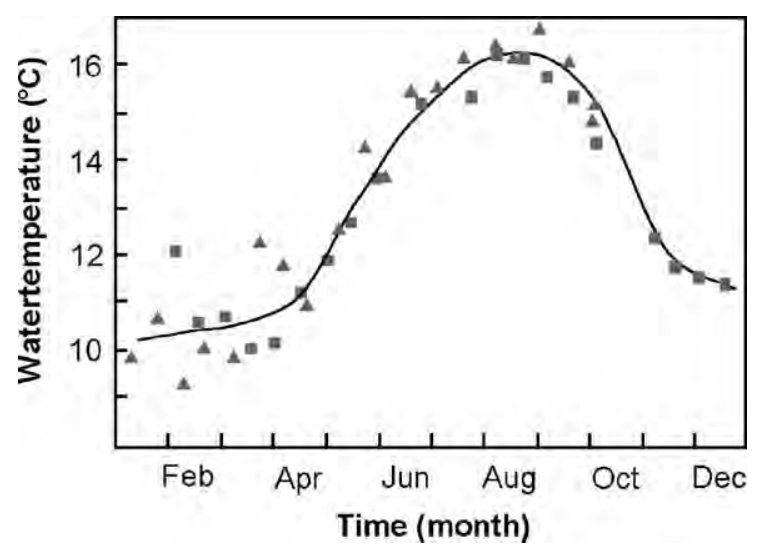

Fig. 1. Sea surface water temperatures in Roscoff (1999: circles; 2000: dots; line: cubic spline through two-year mean values). (Data kindly provided by the Service d'Observation en Milieu LittoralSOMLIT-INSU-CNRS.) concentrations occurred in February (SOMLIT-Database). The investigation area, especially the distribution of substrate types and phytoplankton, is described in Sagan and Thouzeau (1998).

After sampling, animals were immediately transported to the "Station Biologique de Roscoff", where they were maintained in flow-through aquaria until used in experiments or transported to the Alfred Wegener Institute (AWI, Germany). On each occasion shell height $(=$ defined as the maximum distance between the dorsal hinge and ventral margin, Seed, 1980) of a representative subsample was measured to the nearest $0.1 \mathrm{~mm}$ using vernier callipers. A size frequency distribution (SFD) was obtained by pooling individuals using class intervals of $1 \mathrm{~mm}$ size. For size-mass relationships freshly caught animals were dissected and oven dried at $60{ }^{\circ} \mathrm{C}$ for $24 \mathrm{~h}$. Individual gonad and soft tissue dry masses (DM) were weighed to the nearest $0.1 \mathrm{~g}$, linear regression analysis was carried out on log-transformed data, estimating the constants $\mathrm{a}$ and $\mathrm{b}$ of the allometric equation:

$\log (M)=\log (\mathrm{a})+\mathrm{b} \cdot \log (H)$

where $M$ is soft tissue mass ( $\mathrm{g}$ ) of somatic or gonad tissue, respectively, at shell height $H(\mathrm{~mm})$.

\subsection{Growth band reading and analysis}

Bivalve shell growth bands can result from seasonal oscillations in growth, but also from changes in food availability, spawning events or predation attempts. Identification and interpretation of annual growth bands in $A$. opercularis were based on previous studies in this species (Broom and Mason, 1978; Paul, 1980; Hickson et al., 1999) as well as other scallop species (e.g. Dare and Deith, 1990; Heilmayer et al., 2003). For growth band analysis only the left (upper) valve was used. Prior to analysis the shell was cleaned of organic matter with warm $5 \% \mathrm{NaOCl}$ solution, washed with $96 \%$ ethanol, rinsed with water and dried at $60{ }^{\circ} \mathrm{C}$ for $12 \mathrm{~h}$. In each animal, the number of macroscopically visible bands and shell height were recorded. Stable oxygen $\left(\delta^{18} \mathrm{O}\right)$ isotope values in biogenic $\mathrm{CaCO}_{3}$ reflect ambient water temperature and oxygen isotopic composition of seawater, the latter varying with salinity, while carbon $\left(\delta^{13} \mathrm{C}\right)$ isotope values reflect primary production at the 
time of carbonate formation (Erez and Luz, 1983; Hickson et al., 1999). Due to low salinity variations at the site of investigation, the oxygen isotopic composition of seawater should be primarily a reflection of ambient temperature variation. Therefore isotope ratio profiles reflect variations in temperature, shell physiology (related to temperature), primary production and a combination of these (see Wefer and Berger, 1991; Owen et al., 2002a). In environments with a seasonal cycle in temperature and/or primary production such isotope ratios can be used to validate whether or not identified growth bands in the shell of A. opercularis are formed at regular (annual) intervals (for review see Richardson, 2001; Owen et al., 2002a). This approach has recently been applied successfully to identify the growth patterns of various scallop species (e.g. Krantz et al., 1984; Dare and Deith, 1990; Hickson et al., 1999; Lasta et al., 2001; Heilmayer et al., 2003).

For isotope analysis, calcium carbonate powder was sampled from the outer shell layer of four individuals in equally spaced ( $\sim 1 \mathrm{~mm})$ dorso-ventral series using a small dental drill (bit size $0.5 \mathrm{~mm}$ ). $\delta^{18} \mathrm{O}$ and $\delta^{13} \mathrm{C}$ values were determined in the Stable Isotope Laboratory of the Alfred Wegener Institute with a Finnigan MAT251 mass spectrometer coupled to an automatic carbonate preparation device. The results were reported in ppt (\%o deviations related to the Vienna Pee Dee belemnite (VPDB) standard through repeated analyses of National Institute of Standards and Technology (NIST) isotopic reference material 19. The precision of measurements was better than $\pm 0.08 \%$ and $\pm 0.06 \%$ or $\delta^{18} \mathrm{O}$ and $\delta^{13} \mathrm{C}$, respectively, based on routine measurements of a laboratory-working standard.

Assuming that stable isotope analysis will prove the annual formation of one shell growth band each winter (see below) individual age in years was taken to equal the number of growth bands $\mathrm{X}$ in animals sampled in February. Animals caught in June and October were assumed to be $\mathrm{X}+0.33 \mathrm{y}$ and $\mathrm{X}+0.67 \mathrm{y}$ old, respectively. A von Bertalanffy growth model (VBGF) was fitted to the resulting size-at-age data pairs by using a non-linear iterative Newton algorithm (for details Brey, 2001):

$$
\mathrm{H}_{\mathrm{t}}=\mathrm{H}_{\infty} \cdot\left(1-\mathrm{e}^{-\mathrm{K} \cdot(\mathrm{t}-\mathrm{to})}\right)[\mathrm{mm}, \mathrm{y}]
$$

where $H_{\infty}$ is the mean asymptotic height, $K$ is the Brody growth coefficient, $t$ the age and $t_{o}$ is theoretical age at which shell height equals zero.

\subsection{Production $(P)$}

Age specific individual somatic production $\left(P_{S}\right)$ was calculated from the increment in dry tissue mass between consecutive age classes $\left[\mathrm{DM}_{(\mathrm{t}+1)}-\mathrm{DM}_{\mathrm{t}}\right]$ (with $1 \mathrm{~g}$ dry mass $=20.22 \mathrm{~kJ}$; Brey, 2001).

The mass-specific growth rate method could not be used to compute somatic production-to-biomass ratio $(P / B)$ and production of the population, because animals $<35 \mathrm{~mm} \mathrm{H}$ were strongly under-represented in our size frequency distribution owing to the comparatively large $25 \mathrm{~mm} \times 25 \mathrm{~mm}$ mesh size of the dredge. This problem was circumvented by using the annual mortality rate $\mathrm{Z}$ (see below) as a proxy for the somatic production-to-biomass ratio $P_{S} / B$, as $Z$ and $P_{S} / B$ are equal in steady-state (see Allen, 1971) and the catch curve approach to estimate $\mathrm{Z}$ is quite robust against the effects of gear selectivity (Pauly and Munro, 1984). The queen scallop bed at Trezen Vraz is not ephemeral but has been present for at least several decades, as anecdotical evidence (local fishermen reports) and multi-year scientific research (e.g. Sagan and Thouzeau, 1998) indicate. Hence, the assumption of steady-state appears to be justified. Consequently annual somatic production of the population was estimated by:

$\mathrm{P}_{\mathrm{S}}=\mathrm{Z} \cdot \mathrm{M}_{\mathrm{S}} \cdot \mathrm{N} \quad\left[\mathrm{kJ} \mathrm{m}^{-2} \mathrm{y}^{-1}\right]$

where $M_{S}$ is the average individual somatic body mass in our sample and $N$ is the mean abundance of 0.82 ind $\mathrm{m}^{-2}$ provided by Franklin et al. (1980) for the western English Channel.

Gonad production $\left(P_{G, i}\right)$ for each age class was estimated from the decline of gonad mass during spawning in scallops of given age (determined from the von Bertalanffy equation describing shell height as a function of age), determined from logarithmic regressions of gonad mass to size before $\left(M_{G, i}\right.$ (before); February) and after spawning $\left(M_{G, i}\right.$ (after); June) $(1 \mathrm{~g}$ gonad $\mathrm{DM}=23.4 \mathrm{~kJ}$; average from: MacDonald and Thompson, 1985; MacDonald et al., 1991):

$\mathrm{P}_{\mathrm{G}, \mathrm{i}}=\mathrm{M}_{\mathrm{G}, \mathrm{i} \text { (before) }}-\mathrm{M}_{\mathrm{G}, \mathrm{i}(\text { after })} \quad\left[\mathrm{kJ}\right.$ ind $\left.^{-1} \mathrm{y}^{-1}\right]$ 
Individual gonad production is negligible below 30 $\mathrm{mm} \mathrm{H}$ (see Results). Therefore population $\mathrm{P}_{\mathrm{G}} / \mathrm{B}$ ratio was computed from gonad production of total sample and biomass of total sample:

$\mathrm{P}_{\mathrm{G}} / \mathrm{B}=\left(\Sigma \mathrm{N}_{\mathrm{i}} \cdot \mathrm{P}_{\mathrm{G}, \mathrm{i}}\right) /\left(\Sigma \mathrm{N}_{\mathrm{i}} \cdot \mathrm{M}_{\mathrm{S}, \mathrm{i}}\right) \quad\left[\mathrm{y}^{-1}\right]$

where $M_{S}$ is the average individual body mass in class $i$. Hence population gonad production $\left(P_{G}\right)$ can be estimated by:

$\mathrm{P}_{\mathrm{G}}=\left(\mathrm{P}_{\mathrm{G}} / \mathrm{B}\right) \cdot \mathrm{M}_{\mathrm{S}} \cdot \mathrm{N} \quad\left[\mathrm{kJ}\right.$ ind $\left.^{-1} \mathrm{y}^{-1}\right]$

\subsection{Mortality rate (Z)}

The total mortality rate $\mathrm{Z}$ was estimated from the SFD and the von Bertalanffy growth curve by a sizeconverted catch curve (Pauly and Munro, 1984; Brey, 2001):

$\ln \left(\mathrm{N}_{\mathrm{i}} / \Delta \mathrm{t}_{\mathrm{i}}\right)=\mathrm{a}+\mathrm{bt}_{\mathrm{i}} \Leftrightarrow \mathrm{Z}=-\mathrm{b}$

where $N_{i}$ is the number of individuals in size class $i, \Delta t_{i}$ is the time required to grow through this size class and $t_{i}$ is the relative age at the mid-size of class $i$.

\subsection{Metabolism (R)}

Oxygen consumption rates of unfed (deprived of food for at least 3 days), unstressed and inactive animals were used as a proxy of standard metabolic rate as defined by Bayne and Newell (1983) (a detailed description of animal handling is given in Heilmayer and Brey, 2003). Measurements of scallops sampled in June (summer) and October (autumn) were done at ambient temperatures within 5-20 days after sampling. Winter rates were measured on animals sampled in October 1999 and maintained under simulated winter conditions (reduced food, dimmed light) in temperate aquaria with recirculating seawater $\left(10 \pm 0.5^{\circ} \mathrm{C}, 33-34 \mathrm{psu}\right)$. A size range of animals as large as possible was used on each sampling occasion.

Oxygen content was assessed using an intermitted flow system and oxygen microoptodes connected to a Microx 8-array, as previously described in Gatti et al. (2002). Individual metabolic rates $\left(\mathrm{VO}_{2}\right)$ were obtained by comparison with control chambers (no animals). $\mathrm{VO}_{2}$ was expressed as a function of soft tissue dry mass $(D M)$ :

$\log \left(\mathrm{VO}_{2}\right)=\mathrm{a}+\mathrm{b} \cdot \log (\mathrm{DM})$

where $a$ is a constant and $b$ the mass scaling exponent. The model was fitted by least squares linear regression after logarithmic transformation of both variables. In order to compare oxygen consumption among seasons, rates were standardised for body mass (Packard and Boardman, 1999) by:

$\mathrm{VO}_{2, \mathrm{~S}}=\mathrm{VO}_{2} \cdot\left(\mathrm{DM}_{\mathrm{S}} / \mathrm{DM}_{\mathrm{E}}\right)^{\mathrm{b}}$

where $V_{2, S}$ is the metabolic rate of a standard-sized scallop of $1 \mathrm{~g}$ dry mass $\left(D M_{S}\right)$, and $V O_{2}$ and $D M_{E}$ are observed oxygen rate and body mass of the experimental scallop. Oxygen consumed was converted to energy by $1 \mathrm{ml} \mathrm{O}_{2}=20.1 \mathrm{~J}$ (cited in Brey, 2001).

\section{Results}

\subsection{General measurements}

The pooled size-frequency distribution of the year 1999 (Fig. 2) was polymodal and dominated

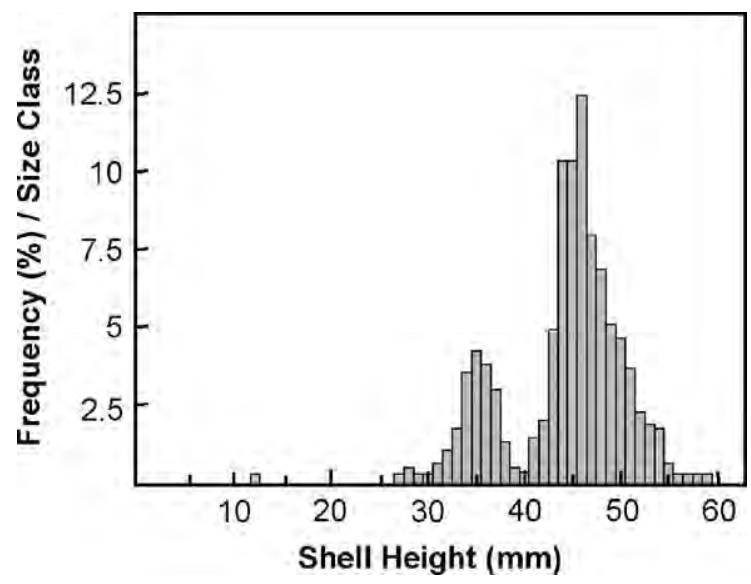

Fig. 2. Aequipecten opercularis. Size frequency distribution (1 mmheight classes, $\mathrm{N}=721)$ of the pooled samples from February $(\mathrm{N}=$ 158), June $(\mathrm{N}=377)$, October $(\mathrm{N}=186) 1999$ taken from the scallop bed of Trezen Vraz. 
$(>70 \%)$ by large individuals $(>41 \mathrm{~mm})$. An ANCOVA showed significant $(\mathrm{p}<0.001)$ seasonal changes in the regressions of somatic and gonad dry mass against shell height (Table 1, both log-transformed). Both somatic dry mass and gonad dry mass of a standard-sized $45 \mathrm{~mm}$ scallop were lowest during the summer period (soma in g DM: 0.371 in June vs. 0.583 in February and 0.847 in October; gonad in g DM: 0.0122 in June vs. 0.0465 in February and 0.0204 in October).

\subsection{Age and growth}

$\delta^{18} \mathrm{O}$ and $\delta^{13} \mathrm{C}$ profiles of the two shells examined showed more or less synchronous cyclical patterns reflecting environmental seasonality (Fig. 3). Over the whole lifetime, $\delta^{18} \mathrm{O}$ values obtained ranged from -0.3 to $+1.1 \%$ (Fig. $3 a$ ) and -0.4 to $+1.3 \%$ dFig. 3b). $\delta^{13} \mathrm{C}$ values ranged from -0.5 to $+0.4 \%$ (Fig. $3 a)$, and from -0.5 to $+0.5 \%$ (Fig. $3 b$ ). There is a distinct spatial coincidence between macroscopically identified growth bands and relative $\delta^{18} \mathrm{O}$ and $\delta^{13} \mathrm{C}$ maxima of the isotope profile (i.e. temperature as well as primary production minima), thus indicating a formation of one growth band each winter.

Size-at-age data of 249 specimens were fitted best by the von Bertalanffy equation:

Table 1

Allometric relationships of tissue mass and shell height in Aequipecten opercularis collected in 1999 from Trezen Vraz

\begin{tabular}{lccc}
\hline & February & June & October \\
\hline Soma & & & \\
$\mathrm{a}$ & -4.151 & -4.921 & -5.078 \\
$\mathrm{~b}$ & 2.369 & 2.716 & 3.028 \\
$\mathrm{r}^{2}$ & 0.41 & 0.76 & 0.71 \\
$\mathrm{~N}$ & 11 & 27 & 61 \\
& & & \\
Gonad & & & -6.922 \\
$\mathrm{a}$ & 12.024 & 4.078 & 3.165 \\
$\mathrm{~b}$ & 6.467 & 0.89 & 0.33 \\
$\mathrm{r}^{2}$ & 0.18 & 27 & 61 \\
$\mathrm{~N}$ & 11 &
\end{tabular}

Regression are of the form $\log (\mathrm{M})=\mathrm{a}+\mathrm{b} \cdot \log (\mathrm{SH})$, where $\mathrm{M}$ is the predicted soft tissue dry mass $(\mathrm{g})$ of the somatic tissue or of the gonad, $\mathrm{SH}=$ shell height $(\mathrm{mm})$, and a and $\mathrm{b}$ are fitted parameters. $\mathrm{N}$ is number of data, $r^{2}$ is the determination coefficient. All equations are statistically significant at $\mathrm{p}<0.001$.

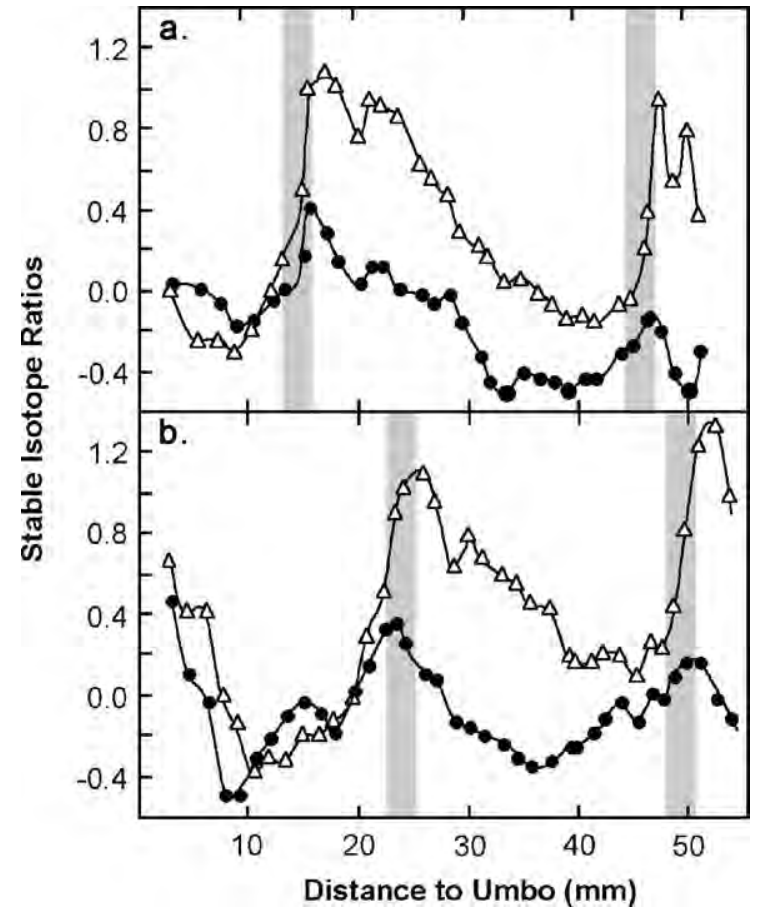

Fig. 3. Aequipecten opercularis. Stable isotope ratio (triangles: $\delta^{18} \mathrm{O}$; dots: $\delta^{13} \mathrm{C}$; weighed moving averages $\left.\mathrm{x}_{1}+3 \cdot \mathrm{x}_{2}+\mathrm{x}_{3}\right) / 5$ ) profiles along transects from umbo to shell edge of two representative individuals (a. $52.18 \mathrm{~mm}$ height, b. $54.2 \mathrm{~mm}$ height). Vertical bars indicate positions of external shell growth bands.

$\mathrm{H}_{\mathrm{t}}=58.9 \mathrm{~mm} \cdot\left(1-\mathrm{e}^{-0.604} \cdot(\mathrm{t}+0.235)\right) ; \mathrm{r}^{2}=0.827$ (Fig. 4). Accordingly, the largest scallop $(\mathrm{H}=58.9$ $\mathrm{mm}$ ) found at Roscoff was about six years old.

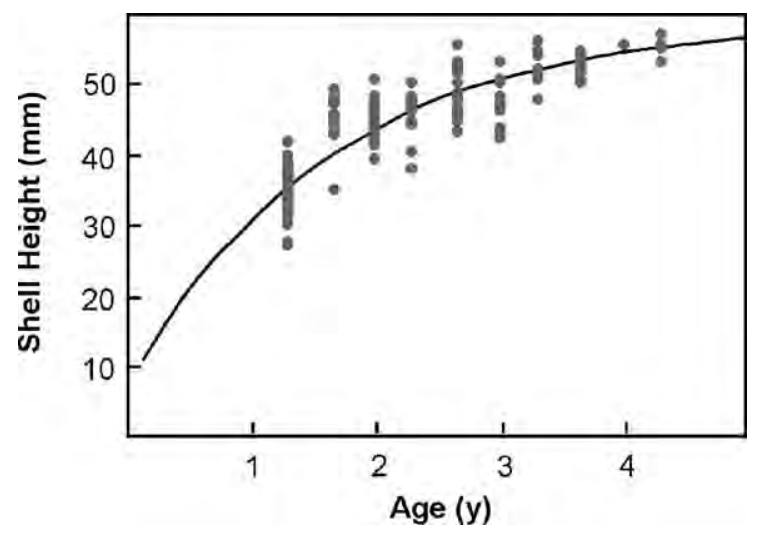

Fig. 4. Aequipecten opercularis. Von Bertalanffy growth function fitted to 249 size-at-age data pairs. Growth function parameters are: $\mathrm{H}_{\infty}=58.9 \mathrm{~mm}, \mathrm{~K}=0.604, \mathrm{t}_{0}=-0.235\left(\mathrm{~N}=249, \mathrm{r}^{2}=0.827\right)$. 


\subsection{Production and mortality}

Individual somatic production increased to a maximum of $10.66 \mathrm{~kJ} \mathrm{yr}^{-1}\left(0.527 \mathrm{~g} \mathrm{DM} \mathrm{y}^{-1}\right)$ at an age of $2 \mathrm{y}$ and decreased thereafter, whereas individual gonad production increased exponentially with shell height, reaching $4.17 \mathrm{~kJ} \mathrm{y}^{-1}\left(0.177 \mathrm{~g} \mathrm{DM} \mathrm{y}^{-1}\right)$ at an age of 6 y (Fig. 5a). Mean annual biomass of $A$. opercularis was $13.67 \mathrm{~kJ} \mathrm{~m}^{-2}\left(0.67 \mathrm{~g} \mathrm{DM} \mathrm{m}^{-2}\right)$, total mortality rate $Z$ amounted to $1.761 \mathrm{y}^{-1}$ (Fig. 6). Correspondingly, annual somatic production $\mathrm{P}_{\mathrm{S}}$ was estimated at $19.74 \mathrm{~kJ} \mathrm{~m}^{-2} \mathrm{y}^{-1}\left(0.976 \mathrm{~g} \mathrm{DM} \mathrm{m}^{-2}\right.$ $\left.\mathrm{y}^{-1}\right)$. Annual gonad productivity $\mathrm{P}_{\mathrm{G}} / \mathrm{B}$ and production $\mathrm{P}_{\mathrm{G}}$ amounted to $0.087 \mathrm{y}^{-1}$ and $0.98 \mathrm{~kJ} \mathrm{~m}^{-2} \mathrm{y}^{-1}$ (0.042 $\left.\mathrm{g} \mathrm{DM} \mathrm{m}^{-2} \mathrm{y}^{-1}\right)$, respectively. Hence, total annual production for the 1999 season amounted to $20.72 \mathrm{~kJ} \mathrm{~m}^{-2} \mathrm{y}^{-1}\left(1.02 \mathrm{~g} \mathrm{DM} \mathrm{m}^{-2} \mathrm{y}^{-1}\right)$, corresponding to an annual $\mathrm{P}_{\text {tot }} / \mathrm{B}$ ratio of 1.848

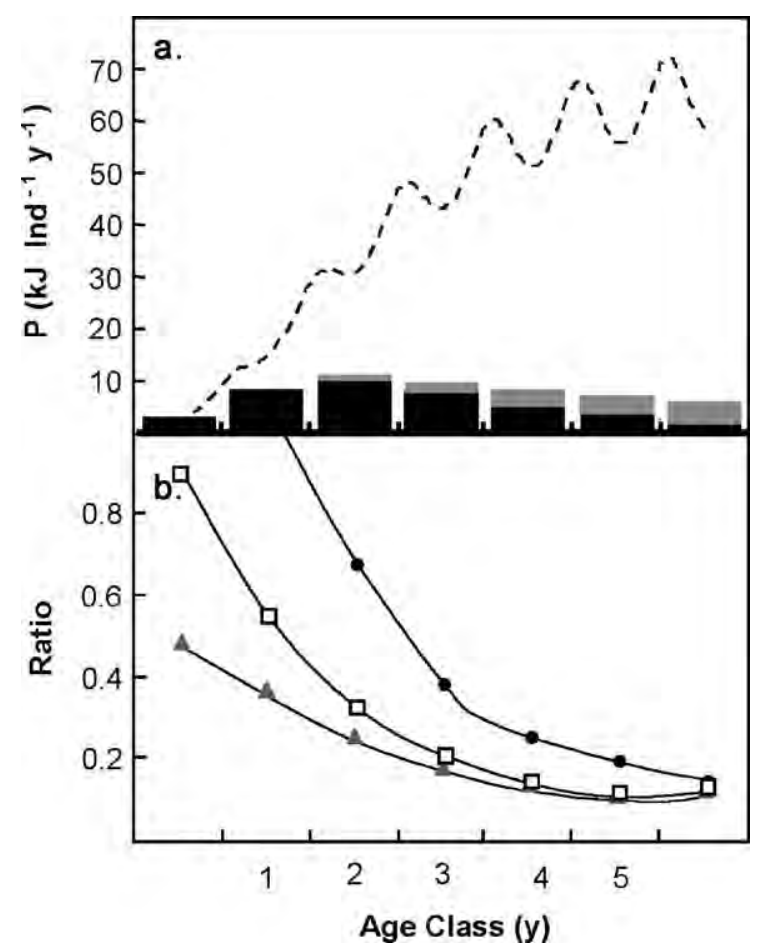

Fig. 5. Aequipecten opercularis. (a) Lifetime production in individual scallops ( $\square$ : somatic production per year class $i$; $\square$ : gonad production per year class $i$; --: respiratory loss per time interval. (b) Mean turnover ratios $(\mathbf{P} / \mathrm{B} ; \square: \mathrm{P} / \mathrm{R})$ and net growth efficiency $\left(\boldsymbol{\Delta}: \mathrm{K}_{2}=\right.$ $\left.\mathrm{P} / \mathrm{A} ; \mathrm{A}=\mathrm{P}_{\mathrm{s}}+\mathrm{P}_{\mathrm{G}}+\mathrm{R}\right)$ for each age-class in A. opercularis from Trezen Vraz.

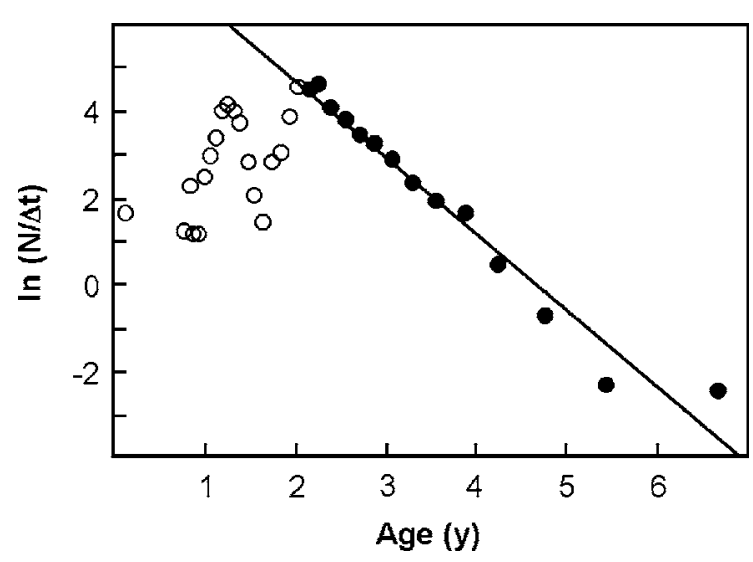

Fig. 6. Aequipecten opercularis. Size-converted catch curve based on the pooled size-frequency sample (Fig. 2) and the von Bertalanffy growth function parameters. Dots: data included in catch curve regression; circles: data excluded from regression:

$\ln \left(N_{i} / d t_{i}\right)=8.237-1.761 \bullet t \Leftrightarrow Z=1.761 \quad\left(r^{2}=0.961\right)$.

$y^{-1}$. The turnover ratio $(P / B)$ calculated for each age class declined with age from 1.45 to 0.14 (Fig. $5 b)$. Similarly $P / R$ ratio and net growth efficiency $\left(K_{2}\right.$ $=\mathrm{P} / \mathrm{A}=\mathrm{P} /(\mathrm{P}+\mathrm{R}))$ decreased but levelled off in the oldest age classes (Fig. 5b).

\subsection{Metabolism}

Metabolic rates were measured in June $(\mathrm{T}=12.4$ $\left.{ }^{\circ} \mathrm{C}\right)$, October $\left(\mathrm{T}=14.4{ }^{\circ} \mathrm{C}\right)$ and December $(\mathrm{T}=10.3$ ${ }^{\circ} \mathrm{C}$ ) over the complete size range of scallops available at Roscoff (June: 0.06-1.81 g DM, October: 0.471.46 g DM, December: 0.13-0.71 g DM). The temperature range examined approximates the annual range encountered by queen scallops in Roscoff waters. The allometric relationships between body dry mass $(\mathrm{DM})$ and metabolic rates $\left(\mathrm{VO}_{2}\right)$ of $A$. opercularis were:

The combined effects of body mass and temperature on metabolic rate can be described by the multiple linear model:

\begin{tabular}{ll}
\hline June & $\log \left(\mathrm{VO}_{2}\right)=2.253+0.654 \cdot \log (\mathrm{DM}) ;$ \\
& $\mathrm{r}^{2}=0.483, \mathrm{~N}=72,34$ animals \\
October & $\log \left(\mathrm{VO}_{2}\right)=2.408+1.014 \cdot \log (\mathrm{DM}) ;$ \\
& $\mathrm{r}^{2}=0.496, \mathrm{~N}=101,34$ animals \\
December & $\log \left(\mathrm{VO}_{2}\right)=2.288+0.707 \bullet \log (\mathrm{DM}) ;$ \\
& $\mathrm{r}^{2}=0.662, \mathrm{~N}=101,22$ animals \\
\hline
\end{tabular}


$\log \left(\mathrm{VO}_{2}\right)=2.093( \pm 0.059)+0.774( \pm 0.029)$

$$
\cdot \log (\mathrm{DM})+0.02( \pm 0.005) \cdot \mathrm{T}
$$

$\mathrm{N}=274, \mathrm{r}^{2}=0.74, \mathrm{~F}=381.311$,

$\mathrm{p}<0.001$, temperature in $^{\circ} \mathrm{C}$.

Standard metabolic rates $\left(\mathrm{VO}_{2, \mathrm{~S}}\right)$ were indistinguishable in June $\left(188.62 \pm 60.32 \mu \mathrm{O}_{2} \mathrm{~g} \mathrm{DM}^{-1}\right.$ $\left.\mathrm{h}^{-1}\right)$ and December $\left(204.17 \pm 67.9 \mu \mathrm{O} \mathrm{O}_{2} \mathrm{~g} \mathrm{DM}^{-1}\right.$ $\mathrm{h}^{-1}$ ), but significantly higher (ANOVA: $p<0.001$ ) in October $\left(264.59 \pm 69.05 \mu \mathrm{O}_{2} \mathrm{~g} \mathrm{DM}^{-1} \mathrm{~h}^{-1}\right)$. This indicated a $30 \%$ seasonal factorial rise over the lowest winter metabolic rates.

\section{Discussion}

\subsection{Age and growth in aequipecten opercularis}

Partitioning of oxygen isotopes between molluscan shells and seawater has historically been assumed to closely approximate in isotopic equilibrium (Witbaard et al., 1994; McConnaughey et al., 1997; Hickson et al., 1999; Schöne et al., 2002; Schöne, 2003). On the other hand more recently Owen et al. $(2002 a, b)$ showed in a thorough laboratory study a positive deviation from equilibrium $(+0.6 \%$ in $\mathrm{Pec}$ ten maximus. Although changes in the $\delta^{18} \mathrm{O}$ and $\delta^{13} \mathrm{C}$ profiles cannot be used for an exact environmental reconstruction the amplitude still can be used as a proxy for relative seasonal oscillation of ambient temperature. The maximum $\delta^{18} \mathrm{O}$-amplitudes in the two shells shown in Fig. 3 correspond to a relative temperature range of 5.6 and $6.8{ }^{\circ} \mathrm{C}$ (according to Craig's palaeo-temperature equation as given by Erez and Luz, 1983), respectively, which is close to the observed annual range of 6.7 ${ }^{\circ} \mathrm{C}$ (Fig. 1). The close spatial coincidence between shell growth band position and both the $\delta^{18} \mathrm{O}$ and $\delta^{13} \mathrm{C}$ peaks in the isotope profiles (Fig. 3) indicate sufficient evidence that bands are formed during times of lowest temperature and low primary production, i.e. one band is formed each winter (for review, see Richardson, 2001). The same pattern was found in populations from Plymouth (December-March: Pickett and Franklin, 1975; Broom and
Mason, 1978) and the North Sea (December-February: Ursin, 1956).

Non-linear growth patterns as derived from the VBGF can be compared indirectly only, e.g. using composite indices of overall growth performance (OGP) (e.g. $\mathrm{P}=\log (\mathrm{K})+\log \left(\mathrm{M}_{\infty}\right)$; Pauly and Munro, 1984). According to Brey (1999), this index is more or less consistent for closely related species. However, in suspension feeding bivalves food supply and/or temperature are the main factors controlling patterns of life history, whereas the genome commits the range of possible adaptations (Stearns, 1976; Widdows et al., 1984; Bayne and Newell, 1983). Hence, the attainable data of Pectinids populations $(\mathrm{N}=134)$ were divided into four broad groups regarding to (i) their hypothetical longevity (estimated as 0.95 - Age at $\mathrm{H}_{\infty}$ derived from the appropriate VBGF), and (ii) the average annual water temperature of the study sites. An auximetric plot of $\log (\mathrm{K})$ versus $\log \left(\mathrm{M}_{\infty}\right)$ is given in Fig. 7. The mean OGPs of the four groups are with one exception (see below) significantly different (ANCOVA with Bonferroni-Dunn post-hoc $\mathrm{p}<0.001$ ). OGP of Aequipecten opercularis falls in the range of other temperate short-lived scallops (TSL, mean $=1.92 \pm 0.26, \mathrm{~N}=31$, Fig. 7). While previous OGP estimates of $A$. opercularis range between 1.9 (Lee, 1973; Taylor and Venn, 1978) and 2.1 (Rolfe, 1973; Allison, 1994), values of the Roscoff population (1.74) appear to be comparatively low, indicating a potentially more stressful environment (i.e. lower food availability, increased depth).

Cold-water long-lived species showed quite similar values $(\mathrm{CLL}$, mean $=1.81 \pm 0.23, \mathrm{~N}=19$, Fig. 7 ) and hence are statistically not distinguishable from the TSL group, albeit having lower $\mathrm{K}$ but higher $\mathrm{M}_{\infty}$ values. The TSL group consists mostly of species belonging to the supragenera Aequipecten and Mimachlamys (suggested by Waller, 1991), while in the CLL all species belong to the supragenus Chlamys. All species of this genus are close relatives, all of them have been considered as subspecies of $C$. islandica at some time of their nomenclatural history (see Waller, 1991). OGP in both warm water short-lived $(\mathrm{WSL}$, mean $=2.89 \pm 0.28, \mathrm{~N}=25$, Fig. 7) and temperate long-lived species (TLL, mean = $2.55 \pm 0.18, \mathrm{~N}=59$, Fig. 7) is distinctly higher 


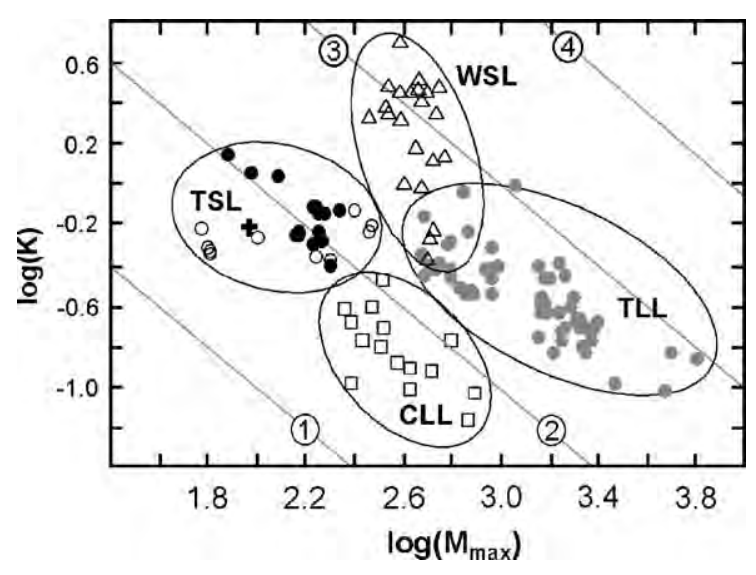

Fig. 7. Auximetric grid comparing overall growth performance of Pectinids. (+): A. opercularis from Roscoff. CLL: cold water longlived species (squares), WSL: warm water short-lived species (triangles); TLL: temperate long-lived species (grey circles); TSL: temperate short-lived species (open circles); A. opercularis (dots). Diagonal lines indicate isolines of growth performance index $\mathrm{P}=$ $\log (\mathrm{K})+\log \left(\mathrm{M}_{\infty}\right)$. Mass data were converted to $\mathrm{kJ}$ by using conversion factors of Brey $(1999,2001)$ and references therein. With one exception mean OGP values of the four groups are significantly different from each other (ANOVA $\mathrm{p}<0.05$, with Bonferroni-Dunn post-hoc test). Mean OGP of TSL is not significantly $(\mathrm{p}=0.076)$ different from CLL. Data sources: CLL: Adamussium colbecki (Stockton, 1984; Berkman, 1990; Heilmayer et al., 2003; Chiantore et al., 2003), Chlamys albidus (Myasnikov and Kochnev, 1988), Chlamys hastata (MacDonald et al., 1991), Chlamys islandica (Vahl, 1981; Lambert and Préfontaine, 1995), Chlamys rosealbus (Silina and Pozdnyakova, 1990); WSL: Amusium spp. (Heald and Caputi, 1981; Williams and Dredge, 1981; DelNorte, 1991); Argopecten purpuratus (Mendo and Jurado, 1993; Wolff, 1987; Yamashiro and Mendo, 1988); TLL: Mizuhopecten yessoensis (Golikov and Scarlato, 1970; Ventilla, 1982; Yoo et al., 1981, cited by Vakily, 1992), Patinopecten caurinus (MacDonald and Bourne, 1987; Ignell and Haynes, 2000), Pecten maximus (Buestel and Laurec, 1975; Dare, 1990; Dare and Deith, 1990; Allison, 1994), Placopecten magellanicus (Brown et al., 1972; Jamieson, 1979; Jamieson et al., 1981; D’Amours and Pilote, 1982; Chouinhard, 1984: all cited in Naidu, 1991; MacDonald and Thompson, 1985; Claereboudt and Himmelman, 1996); TSL: Aequipecten opercularis (Ursin, 1956; Lee, 1973; Antoine, 1979; Aravindakshan, 1955; Askew et al., 1973, all cited by Shumway, 1991; Broom and Mason, 1978; Taylor and Venn, 1978; Richardson et al., 1982; Allison, 1994), Chlamys tehuelcha (Orensanz et al., 1991), Mimachlamys varia (Antoine, 1979; Shafee, 1982; Shafee and Conan, 1984), Zygochlamys patagonica (Valero, 1999; Lasta et al., 2001).

(ANOVA, $\mathrm{p}<0.001$ ) than in the former two groups (TSL, CLL).
In general, phylogenetically 'younger' species of the supragenera belong to temperate groups, thus supporting the general idea (e.g. Arntz and Fahrbach, 1991) that recent scallops evolved from warm water ancestors, i.e. within the supragenus Pecten. Amusium spp. belong to the WSL group, while Pecten maximus belongs to TSL. This remains, however, pure speculation until modern molecular methods (e.g. Canapa et al., 2000) will clarify the hitherto rather uncertain phylogeny of pectinids.

\subsection{Metabolic rates}

Metabolic rate $(\mathrm{R})$ reflects the energy expenditure of an organism, and hence is an important factor in estimating energy flow through both populations and the individual organism (Bayne and Newell, 1983). Rates measured in this study are 2-3 times lower than values for the same species published by McLusky (1973); most likely the latter study used too short an acclimation time to the holding systems $(10-24 \mathrm{~h})$.

Our results indicate a significant seasonality of metabolic activity in $A$. opercularis, as previously observed for many boreal scallops (MacDonald and Thompson, 1985; Bricelj et al., 1987; Shumway et al., 1988). Such seasonal cycles in metabolism result from complex interactions of environmental and endogenous variables acting on the metabolism (for review, see Bayne and Newell, 1983). Body size, environmental temperature and the energetic demands of biosynthesis, particularly those associated with gametogenesis, are considered to have a profound influence on respiratory activity (Shafee, 1982; Bayne and Newell, 1983; Bricelj et al., 1987; MacDonald and Bourne, 1987; MacDonald and Thompson, 1988). The multiple-regression approach used in the present work attempts to quantify the simultaneous effects of body size and seasonal temperature. The equation obtained explains $74 \%$ of total variation recorded in metabolic rate. Because no interactive effects have been considered (for the sake of clarity), the two variables tested can be assumed to account almost completely for the seasonal fluctuations in metabolism. The metabolic mass exponent obtained by this equation $(b=0.774$, S.E. $=0.03)$ is slightly below the mean overall value of 0.807 (S.E. $=0.02)$ derived from a large number of scallop studies $(\mathrm{N}=80,13$ species; Heilmayer et al., unpubl. data). 


\subsection{Individual energy budget model}

The partitioning of ingested or metabolizable energy into maintenance and production and possible trade-offs between growth and reproduction are important to characterise the life-history of species (e.g. Sibly and Calow, 1986; Wieser, 1994). The changing pattern of individual energy expenditure during the 6-y lifespan of A. opercularis clearly illustrates (i) an increasing share of maintenance requirements (expressed as respiration) in the absorbed energy (Fig. 5a, b), and (ii) a progressive transition of production from somatic growth to gonad output with increasing age (Fig. 5a), as previously observed for other scallop species, too, e.g. Mimachlamys varia (Shafee, 1982), Mizuhopecten yessoensis (Fuji and Hashizume, 1974) and Placopecten magellanicus (MacDonald and Thompson, 1985, 1988; Claereboudt and Himmelman, 1996). The general decrease of somatic growth with increasing age (Calow, 1977) is not necessarily caused only by a shift between $\mathrm{P}_{\mathrm{s}}$ and $\mathrm{P}_{\mathrm{g}}$ (Fig. 5a) or the declining ability of the older animals to convert assimilated food into new tissue (Calow and Townsend, 1981), but may also be caused by a shorter growing season of older individuals, as already shown for Chlamys islandica (Vahl, 1981) and Pecten maximus (Chauvaud and Strand, 1999).

Net growth efficiency $\left(\mathrm{K}_{2}\right)$ values for each year of life, which is a measure of the ability to turn assimilated energy into production, decreases during life time from $45 \%$ to $11 \%$ in A. opercularis (Fig. 5b). These data are among the lowest recordings for populations of suspension and deposit feeding bivalve molluscs so far (Bayne and Newell, 1983; Shumway, 1991).

\subsection{Population production and productivity}

With a total $\mathrm{P} / \mathrm{B}$ ratio of $1.848 \mathrm{y}^{-1}$ annual somatic production of $A$. opercularis is estimated at $20.717 \mathrm{~kJ}$ $\mathrm{m}^{-2} \mathrm{y}^{-1}$ in Trezen Vraz and hence in the same order of magnitude as previous estimates from other populations (Broom and Mason, 1978; Taylor and Venn, 1978; Richardson et al., 1982).

The A. opercularis population from Roscoff waters invests only around $5 \%$ of its total annual production into gametes. This is clearly less than in other short- lived scallops (16\% in Mimachlamys varia, Shafee and Conan, 1984) and far below the investment of either long-lived scallops $(\geq 50 \%$ in Placopecten magellanicus and in Patinopecten caurinus; MacDonald and Thompson, 1985; MacDonald and Bourne, 1987) or cold-water scallops (20-30\% in Chlamys islandica and in Adamussium colbecki; Vahl, 1981; Heilmayer et al., 2003). We may, however, have underestimated gonad productivity by assuming one single spawning event during the reproductive season. This view is supported by Aravindakshan (1955) and Ursin (1956), but Taylor and Venn (1978) reported repeated spawning in populations from the Clyde Sea. Conclusive information is lacking so far.

The high $\mathrm{P}_{\text {tot }} / \mathrm{B}$ ratio is in slight contradiction to the observed low OGP value of the population. This might be explained by the comparatively low abundance of large individuals $(>60 \mathrm{~mm})$, which is either a consequence of spatial differences in settlement from year to year (Brand, 1991) or caused by size-selectivity of commercial fisheries.

In conclusion, despite its 6-y lifespan, $A$. opercularis shows some typical features of r-strategy orientated quasi-opportunists, e.g. fast growth and comparatively low reproductive effort. This life strategy combined with environmental variability causes a highly dynamic pattern of occurrence in time and space with typical high-density patches of limited continuance. Locally these patches of $A$. opercularis are likely to play a significant role in system energy flow. Although the sampling extent may not be considered adequate for a precise estimate of population energy parameters, it is still possible to arrive at some conclusions on the individual energy level, which may be considered as a first approximation for future research in this field.

\section{Acknowledgements}

The help of the 'Mya' crew and the colleagues from the logistics of the 'Station Biologique de Roscoff' for fishing and aquarium-maintenance of $A$. opercularis is greatly acknowledged. We are grateful to Günther Meyer and Katrin Blancke (AWI) for technical support in stable isotope analysis. We also thank three anonymous reviewers for constructive comments that greatly improved the manuscript. 


\section{References}

Ansell, A., Dao, J.C., Mason, J., 1991. Three European scallops: Pecten maximus, Chlamys (Aequipecten) opercularis and $C$. (Chlamys) varia. In: Shumway, S.E. (Ed.), Scallops: Biology, Ecology and Aquaculture. Elsevier, Amsterdam, pp. 715-752.

Allen, K.R., 1971. Relation between production and biomass. J. Fish. Res. Bd Can. 28, 1573-1581.

Allison, E.H., 1994. Seasonal growth models for great scallops (Pecten maximus (L.)) and queen scallops (Aequipecten opercularis (L.)). J. Shellfish Res. 13, 555-564.

Antoine, L., 1979. La croissance de la Coquille Saint-Jacques (Pecten maximus) et ses variations en Mer Celtique et en Manche. PhD Thesis. University of Bretagne Occidentale, Brest. 148 pp.

Aravindakshan, I., 1955. Studies on the biology of the queen scallop, Chlamys opercularis (L.). PhD Thesis. University of Liverpool. $79 \mathrm{pp}$.

Arntz, W.E., Fahrbach, E., 1991. El Niño. Klimaexperiment der Natur. Physikalische Ursachen und biologische Folgen Birkhäuser-Verlag, Basel. 264 pp.

Askew, C.G., Dunn, M.R., Reay, P.J., 1973. The fishery for queen scallops in Guernsey 1973. Report of a Preliminary Investigation in 1973 by Marine Resources Research Unit, Portsmouth Polytechnic, UK. Unpubl., 39 pp.

Bayne, B.L., Newell, R.C., 1983. Physiological energetics of marine molluscs. In: Saleuddin, A.S.M., Wilbur, K.M. (Eds.), The Mollusca: Physiology Part 1. Academic Press, Boston, pp. 407-515.

Berkman, P.A., 1990. The population biology of the Antarctic scallop, Adamussium colbecki (Smith 1902) at New Harbor, Ross Sea. In: Kerry, K.R., Hempel, G. (Eds.), Antarctic Ecosystems. Ecological Change and Conservation. Springer-Verlag, Berlin, pp. $281-288$.

Brand, A., 1991. Scallop ecology: distributions and behaviour. In: Shumway, S.E. (Ed.), Scallops: Biology, Ecology and Aquaculture. Elsevier, Amsterdam, pp. 517-584.

Brey, T., 1999. Growth performance and mortality in aquatic macrobenthic invertebrates. Adv. Mar. Biol. 35, 153-223.

Brey, T., 2001. Population Dynamics in Benthic Invertebrates. A Virtual Handbook. Version 01.2. WWW Page http://www. awi-bremerhaven.de/Benthic/Ecosystem/FoodWeb/Handbook/ main.html. Alfred Wegener Institute for Polar and Marine Research, Germany.

Bricelj, V.M., Epp, J., Malouf, R.E., 1987. Comparative physiology of young and old cohorts of bay scallop Argopecten irradians irradians (Lamarck): mortality, growth, and oxygen consumption. J. Exp. Mar. Biol. Ecol. 112, 73-91.

Broom, M.J., 1976. Synopsis of biological data on scallops. FAO Fish. Syn. 114, 1-30.

Broom, M.J., Mason, J., 1978. Growth and spawning in the pectinid Chlamys opercularis in relation to temperature and phytoplankton concentration. Mar. Biol. 47, 277-285.

Brown, B.E., Parrack, M., Flescher, D.D., 1972. Review of the current status of the scallop fishery in ICNAF division 5Z. Int. Comm. Northw. Atl. Fish. (ICNAF) Res. Doc. 72/113, 1-13. Buestel, D., Laurec, A., 1975. Croissance de la coquille St. Jacques
(Pecten maximus L.) en rade de Brest et en baie de Saint Brieuc. Haliotis 5, 173-177.

Calow, P., 1977. Ecology, Evolution and Energetics: A Study in Metabolism Adaptation. In: Macfadyen, A. (Ed.), Advances in Ecological Research, vol. 10. Academic Press, London, pp. $1-61$.

Calow, P., Townsend, C.R., 1981. Resource utilization in growth. In: Townsend, C.R., Calow, P. (Eds.), Physiological Ecology: An Evolutionary Approach to Resource Use. Sinauer Associates Inc., Sunderland, MA, pp. 220-244.

Canapa, A., Barucca, M., Marinelli, A., Olmo, E., 2000. Molecular data from the 16S rRNA gene for the phylogeny of Pectinidea (Mollusca: Bivalvia). J. Mol. Evol. 50, 93-97.

Claereboudt, M., Himmelman, J.H., 1996. Recruitment, growth and production of giant scallops (Placopecten magellanicus) along an environmental gradient in Baie des Chaleurs, eastern Canada. Mar. Biol. 124, 661-670.

Chauvaud, L., Strand, O., 1999. Growth traits in three populations of Pecten maximus. In: Strand, O. (Ed.), Abstracts: 12th International Pectinid Workshop. Inst. Mar. Res., Nordnes, Bergen, pp. $166-167$.

Chiantore, M., Cattaneo-Vietti, R., Heilmayer, O., 2003. Antarctic scallop (Adamussium colbecki) annual growth rate at Terra Nova Bay. Polar Biol. 26, 416-419.

Chouinhard, G.A., 1984. Growth of the sea scallop (Placopecten magellanicus) on the Tormentine Bed, Northumberland Strait. Canadian Atlantic Fisheries Scientific Advisory Committee (CAFSAC) Research Document 84 (61), 1-16.

Dare, P.J., 1990. Use of external shell microgrowth patterns for determining growth and age in the scallop Pecten maximus. Fisheries, Biology and Aquaculture of Pectinids: 8th International Pectinid Workshop, Cherbourg, Plouzane (France), Actes Colloq. IFREMER 17, 211-218.

Dare, P.J., Deith, M.R., 1990. Age determination of scallops, Pecten maximus (Linnaeus, 1758), using stable oxygen isotope analysis, with some implications for fisheries management in British waters. In: Shumway, S.E., Sandifer, P.A. (Eds.), An International Compendium of Scallop Biology and Culture. World Aquacult. Soc., Baton Rouge, pp. 118-133.

D’Amours, D., Pilote, S., 1982. Données biologiques sur le Pétoncle d'islande (Chlamys islandica) et le Pétoncle Géant (Placopecten magellanicus) de la Basse-Côte-Nord du Québec (Secteur de la Tabatire). Cah. Inform. 99, 1-47.

DelNorte, A.G.C., 1991. Fisheries and aquaculture: Philippines. In: Shumway, S.E. (Ed.), Scallops: Biology, Ecology and Aquaculture. Elsevier, Amsterdam, pp. 825-834.

Erez, J., Luz, B., 1983. Experimental paleotemperature equation for planktonic foraminifera. Geochim. Cosmochim. Acta 47, $1025-1031$.

Franklin, A., Pickett, G.D., Holme, N.A., Barrett, R.L., 1980. Surveying stocks of scallops (Pecten maximus) and queens (Chlaamys opercularis) with underwater television. J. Mar. Biol. Ass. UK 60, 181-191.

Fuji, A., Hashizume, M., 1974. Energy budget for a Japanese common scallop, Patinopecten yessoensis (Jay), in Mutsu Bay. Bull. Fac. Fish. Hokkaido Univ. 25, 7-19.

Gatti, S., Brey, T., Müller, W.E.G., Heilmayer, O., Holst, G., 2002. 
Oxygen microoptodes: a new tool for oxygen measurements in aquatic animal ecology. Mar. Biol. 140, 1075-1085.

Golikov, A.N., Scarlato, O.A., 1970. Abundance, dynamics and production properties of populations of edible bivalves Mizuhopecten yessoensis and Spisula sachalinensis related to the problem of organization of controllable submarine farms at the western shores of the Sea of Japan. Helgoländer wiss. Meeresunters. 20, 498-513.

Goulletquer, P., Heral, M., 1997. Marine molluscan production trends in France: from fisheries to aquaculture. NOAA Tech. Rep. 129 (3), 137-162.

Grainger, R.J.R., 1992. ICES Fisheries Statistics: Bulletin Statistique des Pêches Maritimes 1988, vol. 73. ICES, Copenhagen, pp. $64-65$.

Heald, D.I., Caputi, N., 1981. Some aspects of growth, recruitment and reproduction in the southern saucer scallop, Amusium balloti (Bernardi, 1861) in Shark Bay, Western Australia. Dept. Fish. Wildl. (West Australia). Fish. Res. Bull. 25, 1-33.

Heilmayer, O., Brey, T., 2003. Saving by freezing? Metabolic rates of Adamussium colbecki in a latitudinal context. Mar. Biol. 143, 477-484 (DOI 10.1007/s00227-003-1079-7).

Heilmayer, O., Brey, T., Chiantore, M., Cattaneo-Vietti, R., Arntz, W.E., 2003. Age and productivity of the Antarctic scallop (Adamussium colbecki) in the Ross Sea. J. Exp. Mar. Biol. Ecol. 288, 239-256.

Hickson, J.A., Johnson, A.L.A., Heaton, T.H.E., Balson, P.S., 1999. The shell of the queen scallop Aequipecten opercularis (L.) as a promising tool for palaeoenvironmental reconstruction: evidence and reasons for equilibrium stable-isotope incorporation. Palaeogeogr. Palaeoclimatol. Palaeoecol. 154, 325-337.

Ignell, S., Haynes, E., 2000. Geographic patterns in growth of the giant Pacific sea scallop, Patinopecten caurinus. Fish. Bull. 98, $849-853$.

Jamieson, G.S., 1979. Status and assessment of Northumberland Strait scallop stocks. Fish Mar. Serv. Tech. Rept. 904, 1-34.

Jamieson, G.S., Kerr, G., Lundy, M.J., 1981. Assessment of scallop stocks on Browns and German Banks-1979. Can. Tech. Rept. Fish. Aquat. Sci. 1014. 17 pp.

Krantz, D.E., Jones, D.S., Williams, D.F., 1984. Growth rates of the sea scallop, Placopecten magellanicus, determined from the ${ }^{18} \mathrm{O} /{ }^{16} \mathrm{O}$ record in shell calcite. Biol. Bull. 167, 186-199.

Lambert, J., Préfontaine, G., 1995. The Iceland scallop (Chlamys islandica) in Nunavik. Can. Tech. Rep. Fish. Aquat. Sci.; Rapp. Tech. Can. Sci. Halieut. Aquat. 0 (2071), 1-40.

Lasta, M., Valero, J., Brey, T., Bremec, C., 2001. Zygochlamys patagonica (King and Broderip) beds on the Argentinian shelf. Part II: Population dynamics of $Z$ patagonica. Arch. Fish. Mar. Res. 49, 125-137.

Lee, T., 1973. Scallop and queen scallop survey along the east and south-east coasts of Ireland-August 1972. Resour. Rec. Pap. Bord Iascaigh Mhara Fish. Dev. Div. 23.

MacDonald, B.A., Bourne, N.F., 1987. Growth, reproductive output, and energy partitioning in weathervane scallops, Patinopecten caurinus, from British Columbia. Can. J. Fish. Aquat. Sci. $44,152-160$.

MacDonald, B.A., Thompson, R.J., 1985. Influence of temperature and food availability on the ecological energetics of the giant scallop Placopecten magellanicus: II. Reproductive output and total production. Mar. Ecol. Prog. Ser. 25, 295-303.

MacDonald, B.A., Thompson, R.J., 1988. Intraspecific variation in growth and reproduction in latitudinally differentiated populations of the giant scallop Placopecten magellanicus (Gmelin). Biol. Bull. 175, 361-371.

MacDonald, B.A., Thompson, R.J., Bourne, N.F., 1991. Growth and reproductive energetics of three scallop species from British Columbia (Chlamys hastata, Chlamys rubida and Crassadoma gigantea). Can. J. Fish. Aqua. Sci. 48, 215-221.

McConnaughey, T.A., Burdett, J., Whelan, J.F., Paull, C.K., 1997. Carbon isotopes in biological carbonates: respiration and photosynthesis. Geochim. Cosmochim. Acta 61, 611-622.

McLusky, D.S., 1973. The effect of temperature on the oxygen consumption and filtration rate of Chlamys (Aequipecten) opercularis (L.) (Bivalvia). Ophelia 10, 141-154.

Mendo, J., Jurado, E., 1993. Length-based growth parameter estimates of the Peruvian scallop (Argopecten purpuratus). Fish. Res. 15, 357-367.

Myasnikov, V.G., Kochnev, Y.P., 1988. Lifespan, growth and sex structure of scallop (Chlamys albidus) off the Kuril Islands. Marine Commercial Invertebrates, Collected Papers. VNIRO, Moscow, pp. 153-166.

Naidu, K.S., 1991. Sea scallop, Placopecten magellanicus. In: Shumway, S.E. (Ed.), Scallops: Biology, Ecology and Aquaculture. Elsevier, Amsterdam, pp. 861-898.

Orensanz, J.M., Pascual, M., Fernández, M., 1991. Fisheries and aquaculture: Argentina. In: Shumway, S.E. (Ed.), Scallops: Biology, Ecology and Aquaculture. Elsevier, Amsterdam, pp. $981-1000$.

Owen, R., Kennedy, H., Richardson, C., 2002a. Experimental investigation into partitioning of stable isotopes between scallop (Pecten maximus) shell calcite and sea water. Palaeogeo. Paleoclim. Paleoecol. 185, 163-174.

Owen, R., Kennedy, H., Richardson, C., 2002b. Isotopic partitioning between shell calcite and seawater: effect of shell growth rate. Geochim. Cosmochim. Acta 66, 1727-1737.

Packard, G.C., Boardman, T.J., 1999. The use of percentages and size-specific indices to normalize physiological data for variation in body size: wasted time, wasted effort? Comp. Biochem. Physiol. 122, 37-44.

Paul, J.D., 1980. Salinity-temperature relationships in the queen scallop Chlamys opercularis. Mar. Biol. 56, 295-300.

Pauly, D., Munro, J.L., 1984. Once more on the comparison of growth in fish and invertebrates. Fishbyte 2, 21.

Pickett, G.A., Franklin, A., 1975. The growth of queen scallops (Chlamys opercularis) in cages off Plymouth, South-West England. ICES CM (K25). 4 pp.

Richardson, C.A., 2001. Molluscs as archives of environmental change. Oceanogr. Mar. Biol. 39, 103-164.

Richardson, C.A., Taylor, A.C., Venn, T.J., 1982. Growth of the queen scallop Chlamys opercularis in suspended cages in the Firth of Clyde. J. Mar. Biol. Ass. UK 62, 157-169.

Rolfe, M.S., 1973. Notes on queen scallops and how to catch them. Shellfish Inf. Leafl. Minist. Agric. Fish. Food, U.K. 27. $13 \mathrm{pp}$.

Sagan, G., Thouzeau, G., 1998. Variabilité spatio-temporelle de la 
biomasse microphytobenthique en rade de Brest et en Manche occidentale. Oceanol. Acta 21, 677-694.

Schöne, B.R.A., 2003. A 'clam-ring' master-chronology constructed from a short-lived bivalve mollusc from the northern Gulf of California, USA. The Holocene 13, 39-49.

Schöne, B.R., Lega, J., Flessa, K.W., Goodwin, D.H., Dettman, D.L., 2002. Reconstructing daily termperatures from growth rates of intertidal bivalve mollusc Chione cortezi (northern Gulf of California, Mexico). Palaeogeo. Palaeoclimat. Palaeoecol. $184,131-146$.

Seed, R., 1980. Shell growth and form in the Bivalvia. In: Rhoadas, D.C., Lutz, R.A. (Eds.), Skeletal Growth of Aquatic Organisms. Plenum Press, New York, pp. 23-68.

Shafee, M.S., 1982. Seasonal variation in oxygen consumption rates of the black scallop Chlamys varia (L.) from Lanvéoc (Bay of Brest). Oceanol. Acta 5, 189-197.

Shafee, M.S., Conan, G., 1984. Energetic parameters of a population of Chlamys varia (Bivalvia: Pectinidae). Mar. Ecol. Prog. Ser. 18, 253-262.

Shumway, S.E., 1991. Scallops: Biology, Ecology and Aquaculture. Elsevier, Amsterdam.

Shumway, S.E., Barter, J., Stahlnecker, J., 1988. Seasonal changes in oxygen consumption of the giant scallop, Placopecten magellanicus (GMELIN). J. Shellfish Res. 7, 77-82.

Sibly, R.M., Calow, P., 1986. Physiological Ecology of Animals. An Evolutionary Approach. Blackwell Scientific Publications, Oxford.

Silina, A.V., Pozdnyakova, L.A., 1990. Growth of the scallop Chlamys rosealbus in the Sea of Japan. Russ. J. Mar. Biol. 16, 32-36.

Stearns, S.C., 1976. Life history tactics: A review of the ideas. Q. Rev. Biol. 51, 3-47.

Stockton, W.L., 1984. The biology and ecology of the epifaunal scallop Adamussium colbecki on the west side of McMurdo Sound, Antarctia. Mar. Biol. 78, 171-178.

Taylor, A.C., Venn, T.J., 1978. Growth of the queen scallop, Chlamys opercularis, from the Clyde Sea area. J. Mar. Biol. Ass. UK 58, 687-700.

Ursin, E., 1956. Distribution and growth of the queen, Chlamys opercularis (Lamellibranchiata) in Danish and Faroese waters. Medd. Dan. Fisk.-Havunders. 1, 1-31.

Vahl, O., 1972. Particle retention and relation between water transport and oxygen uptake in Chlamys opercularis (L.) (Bivalvia). Ophelia 10, 67-74.
Vahl, O., 1981. Energy transformation by the Iceland scallop, Chlamys islandica (O.F. Müller), from $70^{\circ} \mathrm{N}$ : II. The population energy budget. J. Exp. Mar. Biol. Ecol. 53, 297-303.

Vakily, J.M., 1992. Determination and comparison of bivalve growth, with emphasis on Thailand and other tropical areas. ICLARM Tech. Rep. 36. 125 pp.

Valero, J., 1999. Variación estacional, espacial e interannual en el crecimiento de vieira patagónica (Zygochlamys patagonica) en la plataforma argentina. Informe Final - Contrato IICA.

Ventilla, R.F., 1982. The scallop industry in Japan. Adv. Mar. Biol. 20, 309-382.

Waller, T.R., 1991. Evolutionary relationships among commercial scallops (Mollusca: Bivalvia: Pectinidae). In: Shumway, S.E. (Ed.), Scallops: Biology, Ecology and Aquaculture. Elsevier, Amsterdam, pp. 1-73.

Wefer, G., Berger, W.H., 1991. Isotope paleontology: growth and composition of extant calcareous species. Mar. Geol. 100, 207-248.

Widdows, J., Donkin, P., Salkeld, P.N., Cleary, J.J., Lowe, D.M., Evans, S.V., Thomson, P.E., 1984. Relative importance of environmental factors in determining physiological differences between two populations of mussels (Mytilus edulis). Mar. Ecol. Prog. Ser. 17, 33-47.

Wieser, W., 1994. Cost of growth in cells and organisms: general rules and comparative aspects. Biol. Rev. 68, 1-33.

Williams, M.J., Dredge, M.C.L., 1981. Growth of the saucer scallop, Amusium japonicum balloti Habe in central eastern Queensland. Aust. J. Mar. Freshw. Res. 32, 657-666.

Witbaard, R., Jenness, M.I., Van der Borg, K., Ganssen, G., 1994. Verification of annual growth increments in Arctica islandica L. from the North Sea by means of oxygen and carbon isotopes. Neth. J. Sea Res. 33, 91-101.

Wolff, M., 1987. Population dynamics of the Peruvian scallop Argopecten purpuratus during the El Nino phenomenon of 1983. Can. J. Fish. Aquat. Sci. 44, 1684-1691.

Yamashiro, C., Mendo, J., 1988. Crecimiento de la Concha de Abanico (Argopecten purpuratus) en la Bahia Independencia, Pisco, Perœ. Memorias del 2do Congreo Latinoamericano sobre Ciencias del Mar, Lima, Perœ, pp. 163-168.

Yoo, S.K., Ryu, H.Y., Park, K.Y., 1981. The growth of the cultured, Patinopecten yessoensis. Bull. Korean Fish. Soc. 14, 221-226. 